\title{
AN INDIAN PERSPECTIVE ON JUDICIAL REVIEW
}

\author{
ANWESHA TRIPATHY ${ }^{1} \&$ NILANJAN CHAKRABORTY ${ }^{2}$ \\ ${ }^{1}$ Asst.Professor, Faculty of Legal Studies, Siksha O Anusandhan (Deemed To Be University), Odisha \\ ${ }^{2}$ Asst.Professor, Faculty of Legal Studies, Siksha O Anusandhan (Deemed To Be University), Odisha
}

\begin{abstract}
The research paper deals with the idea of judicial review and how it began in the Marbury v. Madison case back in 1803. The paper also clarifies the basic concepts of natural justice before addressing the various solutions under review, such as certiorari, prohibition, habeas corpus, mandamus, and quo warranto.The paper ends by addressing the importance of judicial review in a democracy where authority can often go unbridled.The principle chief justice Coke declared, the legitimacy of the legislation was firmly challenged in colonial tribunals in many cases. Following, the United States of America set the world's legal standards in advance as a novel republic description.The judicial review may serve as a verified command on the republic, while disintegrating obsessed with monocracy, and giving in to the offensive law. India itself adopted in its Constitution, the clause of judicial oversight. The Indian Constitution has its own singularity and individuality.
\end{abstract}

KEYWORDS: Democracy, Judicial Review, Natural Justice, Writs

Received: Jun 08, 2020; Accepted: Jun 28, 2020; Published: Aug 27, 2020; Paper Id.: IJMPERDJUN2020915

\section{INTRODUCTION}

The principle chief justice Coke declared, the legitimacy of the legislation was firmly challenged in colonial tribunals in many cases. Following, the United States of America set the world's legal standards in advance as a novel republic description. As deemed to be recognition and safeguard of the rights of the farmers since time immemorial, their commitment to the protection and development of and making plant genetic resources available for the development of new ones varieties of plants.India itself adopted in its Constitution, the clause of judicial oversight. The Indian Constitution has its own singularity and individuality.

The Chief Justice of Indian Supreme Court, Patanjali Shastri, remarked while logically, the court indicated endless heaviness to the judgment of jurisdiction. The judiciary cannot reward its personal responsibility for overseeing the finish Constitutionality of the legislation being tested. It have now laid down the innovative criteria of contemporary statutory regulations.

At first, due to the separation of powers, judicial review as a concept was not favored by most European nations. Though countries like Germany, Austria, and Switzerland were influenced by the United States along with several common wealth nations and incorporated their own versions of judicial review into their legal systems. The concept has since emerged and developed as one of those nations' governing pillars.

At first, due to the separation of powers, most European nations didn't favor judicial review as a concept. While countries such as Germany, Austria, and Switzerland were influenced by the United States along with other 
common wealth nations, their own forms of judicial review were integrated into their legal systems.Countries having a written constitution face this aspect of judicial review more as the courts can assess the validity of a provision more effectively. A superior court can also re-examine a lower court's decision through judicial review and strike it down if the decision is found to be wrong.

Judicial review is something of a power. It allows the judiciary to reach out to other government organs, such as the legislature and executive, and to monitor their actions and ensure that nothing is done that does not comply with the constitution of the country. So, the judicial review function can be said to be twofold that is, legitimizing the government's actions and safeguarding the constitution against any infringements.

\section{DISCUSSIONS}

\section{Principles of Natural Justice}

Natural justice is a very crucial aspect of constitutional law, and has existed since ancient times. "This can be understood as simple and elementary Justice, as distinct from complex, sophisticated and technical Justice."'The definition of natural justice also varies from country to country and, while the basic idea of fair play in practice might be the same, the concepts applied are not universal in nature."'Natural Justice concepts are easy to pronounce but their exact nature is much less easy to describe." Repeated views have been expressed that the definition of natural justice is an ambiguous one and that it cannot be followedhowever, this view is flawed as it seeks to compartmentalize the concept as something that is almost non-existent because it cannot be weighed and measured. In AK Kraipak v. Union of India it has been said that "Natural Justice's horizon is continually expanding.The question of how far administrative enquiries govern the principles of natural justice came before the Queens Bench Division in re H.K. (An Infant), QB 617 1967-2, at p. 630. Therein came a consideration for the validity of the action taken by an immigration officer.

Natural Justice rules are in place to ensure there is no miscarriage of justice. Such principles can only be applicable in any field which is not protected by land law. The theory has evolved over time, and the principles found within the theory have been applied to others.Previously, the principle was considered to consist of two principles, namely Nemo debet esse judex propria causa and audi alteram partem, which means that no one is to be a judge in his own case and no decision is to be taken against a party without giving the party the opportunity to be heard separately first.A third provision was also envisaged, namely that quasi-judicial inquiries must be performed in their faith without prejudice and not arbitrary or unfair, although many of the most subordinate provisions have been applied to Natural Justice law over the years.It was the view of the Courts until quite recently that there was no space for the application of the rules of natural justice unless the body concerned was bound by the statute by which it functioned to act judicially."Natural Justice concepts are easy to pronounce but their exact nature is much less easy to describe." Repeated views have been expressed that the definition of natural justice is a ambiguous one and that it cannot be followed.Enquiries that were at one time considered administrative are now considered in character as quasi-judicial.The aim of both quasi-judicial enquiries and administrative enquiries is to arrive at a just decision. In an administrative enquiry an unjust decision may have a more farreaching effect than a quasi-judicial enquiry decision.

\section{Judicial Views of India}

Under the 1935 Constitution Act of India, which generated centralized tribunal has retained its permanent power. The Act clearly visualized the unified system of the Govt., which demarcated the statute compasses between the federal units and 
center.It was felt necessary to create all the courts in India to decide on the conflict claim, with particular reference to the federal states' three lists with the core. The federal States form the legislative jurisdiction provincial territory.

The central government's disaffection of controls among states and those are significant federal system structures; where dissemination occurs there will be disagreement over the forces between the states and the Centre. Hence becoming such differences of opinion are largely respectful and outline vigilant province of forces there must be proper, fair and legal provision between the federal states and the Centre authority.

Interpreting the legislative rights of certain bodies of the federal judiciary is in there, government. Controversy between States and the Centre, and the judiciary between the States and the State, is the equitable institution legitimate and authorized to interpret the Constitution as to the resolution of the fairly contested.

\section{Supremacy of Indian Judiciary}

The incremental progression of the judicial claim of dominance can be seen meanwhile equality in front of the S.C.I. by reviewing the S.C.I. case of rule. In the Supreme Court had taken very cautionary, modest and slow steps in the early decades. Nevertheless, at the same time, the development ofJurisprudence and the supremacy of justice.

On the issue of law and fact, which is public in nature the credibility, which the Indian President stated to the judiciary, for judgment and conspiracy. The S.C.I. has been instrumental in offering legal advice to the Indian President.The court has the power to safeguard the constitution supremacy by the definition and enforcing of conditions of research in full settlements within a legal context.The judiciary has taken care of itself real main position in the federation problem and the economy, where the controversy arose between the State and the Centre.

The Allahabad High Court dispute with the Legislative Assembly formerly come from Utter Pradesh with the S.C.I. The judiciary authorizes the application of aggrieved person questioning sentence imposed on him by the Assembly of legislation, under the luxury of opening. The tribunal had ordered the discharge person depressed on surety.The Legislative Assembly deemed the disdain an suit against the judge and the lawyer involved, who incited the High Court to take action. The Legislative Assembly and its officials who have taken measures in this matter, the High Court gave restraining orders.

When the on this point dispute emerged. It was spoken of as the Indian pursuant to Article one hundred and fourty-three, demanding investigation, about the fight. Where was the contempt taken place, outdoor or inside an assembly Four Wall? Whether the Assembly was sole and exclusive question judge? To enforce its decision as to whether the assembly gave. To enforce its decision on whether or not the assembly issued an unspeakable or warrant general? Where did the disdain go?

\section{Remedies of Judicial Review}

Habeas Corpus, mandamus, certiorari, prohibition and quo warranto gave the Supreme Court and the High Court the power to issue writs. The Supreme Court may use these writs to enforce the Fundamental Rights while the High Courts may use the rits to enforce the Fundamental and any other rights or purposes."The Supreme Court held that 'for any other purpose' was intended to enforce any statutory and common law right." These remedies were explained below: 


\section{Writ of Certiorari}

The High Court's use Certiorari 's writing to direct the lower courts to transfer the record of the pending proceedings to them so that they can assess them and quash them if necessary.Atkin L.J observed that the certiorari 's letter could be issued "whenever any person with legal authority finds out questions that affect the rights of subjects and encompasses the duty to act in a judicial manner, act outside their legal authority."

In the case of Madhya Pradesh State Radheshyam Khare v. The Supreme Court observed that the document consisted of four components, namely (a) a body of persons (b) with legal authority (c) to determine matters affecting the rights of subjects and (d) a duty to act in a judicial manner.

\section{Prohibition}

This writ is also handed out by a higher court to an inferior court. The higher court, by this writing, prevents the lower court from acting out of jurisdiction or exceeding the jurisdiction it has been granted.

The writ is available only against a public authority or authority established by a statute that exercises judicial or quasi-judicial functions. Only an individual who has been grieved by a decision or action shall apply for the writ. The writing has conditions, such as:

- Like writ of certiorari, prohibition can be issued only against authorities exercising judicial or quasi-judicial functions.

- The writ can be issued only where such judicial or quasi-judicial authority assumes jurisdiction which does not have or exceeds the jurisdiction which it has or where proceedings are in contravention of law or principles of natural justice.

- At the time of the issue of the writ, proceedings must be pending.

- Where proceedings are partly within the jurisdiction of such authority and partly in excess of its jurisdiction, the writ will lie only against that part of the proceedings which is in excess of its jurisdiction.

- The authority should also continue to function. If before the issue of the writ the authority becomes functus, officio, prohibition will not be appropriate remedy.

- There should not be deliberate concealment or misstatement of material facts which may mislead the court.

\section{Mandamus}

It is given to any person or entity who has a public obligation to perform a task that is his obligation to perform. It is issued by the Supreme Court or a High Court in the form of an order to any court, public authority, government or corporation or individual dedicated to public duty commanding such a court, public authority, government or corporation or person.

"It is in the nature of command demanding any particular act to be done or not to be done by any individual holding public office, temporary or permanent or by a corporation or inferior court."

This writing safeguards legal rights, applies constitutional limitations, corrects the error of law and breaches the

\footnotetext{
${ }^{1}$ Article 32, Right to Constitutional Remedies, Constitution of India, 1950 
principles of natural justice, and forces any person or authority to fulfill a public duty imposed by law upon him. The enforcement of departmental directives that do not have substantive force cannot be given.

\section{Habeas Corpus}

This writing is in line with the right to freedom of movement. This writing commands any restricted person to be set free from his confinement without any reasonable justification. It's in the form of an order issued by a state's High Court if a person has been jailed for no apparent reason. Habeas Corpus is demanding that the court know why the person was kept in captivity.

"The writ of habeas corpus has taken great relevance in the administrative procedure as wide powers of detainment are given on the administrative authorities in the current times. The bases of habeas corpus are the same basis of judicial review based on ultra vires doctrine. So if the detention powers are utilized mala fide or based on extraneous or irrelevant contemplations or are utilized in infringement of statutory provisions, the writ of habeas corpus will issue to nullify such a detainment. There is no need for a separate certiorari.",2

\section{Qua Warranto}

The holder of a public office is challenged by Quo Warranto's writ regarding the legitimacy of his seat in the legislature. The officer is called upon to show reason as to what is the authority under which he occupies the post. This legislation gives the authority to control the executive activity to the judiciary.

Could not use the writ against a private office. The writ may allow the offending office bearer 's actions to become null and void ab initio. The essence of the disqualification would depend on it. If the disqualification is of a legal sort, the activities will not be null and void and the de facto office principle will be extended to save certain actions.

\section{CONCLUSIONS}

The Greek philosopher Aristotle was of the view that people who exercise power that is unchecked are often found to be favouring themselves and others who are like them. This observation stands valid for democracy as well. It is this unfettered power that the judicial review protects the citizens from. This is not because of the reason that the judiciary is more capable of making laws, but because of the fact that it takes away the concentration of law making power from one single entity. Judicial review does not take away the law making power from the hands of the legislature but it gives a share of the same to the judiciary. This exercise prevents the acts of the legislature from going unbridled.

It must always be remembered that a step taken in a new direction is fraught with the danger of being a likely step in a wrong direction. In order to be a path-breaking trend it must be a sure step in the right direction. Any step satisfying these requirements and setting a new trend to achieve justice can alone be a New Dimension of Justice and a true contribution to the growth and development of law meant to achieve the ideal of justice.

\section{REFERENCES}

1. Ginsburg, T. (2003). Judicial review in new democracies: Constitutional courts in Asian cases. Cambridge University Press.

2. Frickey, P. P., \& Smith, S. S. (2001). Judicial review, the congressional process, and the federalism cases: An interdisciplinary critique. Yale LJ, 111, 1707.

\footnotetext{
${ }^{2}$ Poonam Rawat, Mode of Judicial Review of Administrative Actions, Journal of law College Dehradun.
} 
3. Cane, P. (2004). Understanding judicial review and its impact. Judicial Review and Bureaucratic Impact, 32-33.

4. Utter, R. F., \& Lundsgaard, D. C. (1993). Judicial review in the new nations of Central and Eastern Europe: some thoughts from a comparative perspective. Ohio St. LJ, 54, 559.

5. Mashaw, J. L. (2010). Rethinking Judicial Review of Administrative Action: A Nineteenth Century Perspective. Cardozo L. Rev., 32, 2241. 